\title{
PENGARUH BRAND EQUITY TERHADAP NIAT BELI KONSUMEN DIMEDIASI BRAND PREFERENCE
}

\author{
Ida Bagus Bayu DP ${ }^{1}$ \\ Eka Sulistyawati ${ }^{2}$ \\ ${ }^{1,2}$ Fakultas Ekonomi dan Bisnis Universitas Udayana, Bali, Indonesia \\ e-mail: idabagusbayu@ gmail.com
}

\begin{abstract}
ABSTRAK
Tujuan penelitian ini adalah untuk menganalisis pengaruh brand equity terhadap niat beli konsumen dimediasi brand preference. Penelitian ini dilakukan di Kota Denpasar dengan teknik analisis data path analisis. Ukuran sampel yang didapat dengan menggunakan metode purposive sampling sebanyak 110 responden. Berdasarkan hasil analisis dapat dikemukakan bahwa brand equity berpengaruh positif dan signifikan terhadap brand preference pada produk Lacoste di Kota Denpasar. Brand equity berpengaruh positif dan signifikan terhadap niat beli konsumen pada produk Lacoste di Kota Denpasar. Brand preference berpengaruh positif dan signifikan terhadap niat beli konsumen pada produk Lacoste di Kota Denpasar. Brand preference memediasi pengaruh positif brand equity terhadap niat beli konsumen pada produk Lacoste di Kota Denpasar. Produsen Lacoste sebagai distributor harus mampu menghadapi masalah brand equity yang dikeluhkan oleh konsumen, memperhatikan design, model dan kualitas produk dengan inovasi yang lebih menarik berbeda dengan merek pesaing.
\end{abstract}

Kata kunci: brand equity, brand preference, niat beli

\begin{abstract}
The purpose of this study was to analyze the effect of brand equity on consumer purchase intentions mediated by brand preference.. The sample size obtained by using purposive sampling method as many as 110 respondents. Based on the results of the analysis it can be stated that brand equity has a positive and significant effect on brand preference on Lacoste products in Denpasar City. Brand equity has a positive and significant effect on consumers' purchase intentions on Lacoste products in Denpasar City. Brand preference has a positive and significant effect on consumers' purchase intentions on Lacoste products in Denpasar City. Brand preference mediates the positive influence of brand equity on consumer purchase intentions on Lacoste products in Denpasar City. Lacoste producers as distributors must be able to deal with brand equity problems that consumers complain about, pay attention to design, model and product quality with more attractive innovations that are different from competing brands. Paying attention to the brand preference of the lacoste brand such as appearance and color so consumers know that the lacoste brand is really not a counterfeit.
\end{abstract}

Keywords: brand equity, brand preference, purchase intention 


\section{PENDAHULUAN}

Perkembangan dunia usaha saat ini mengalami kemajuan yang sangat pesat. Setiap perusahaan berusaha untuk menciptakan produk baru ataupun melakukan inovasi terhadap produk yang sudah ada. Semua itu dilakukan untuk menarik perhatian konsumen dengan harapan agar perusahaan dapat menjadi market leader (Eko dan Budi, 2013). Salah satu usaha yang dilakukan oleh perusahaan untuk mewujudkan hal tersebut adalah dengan melakukan strategi pemasaran. Strategi pemasaran merupakan suatu langkah atau tindakan yang direncanakan oleh produsen sebelum produk dipasarkan ke konsumen (Saadia, 2013). Pemasaran dengan sistem dan aktivitasnya, mampu mengakrabkan konsumen dengan produk dan merek perusahaan yang ditawarkan. Saat itu pemasaran tidak hanya tertuju pada fungsi produk saja, namun lebih pada persaingan merek (Johan, 2010).

Meningkatnya budaya niat beli di Indonesia, terutama di bidang fashion dapat kita lihat dari semakin banyaknya mal di Indonesia dan Kota-kota besar seperti Bali yang tidak kalah hebat dengan mal-mal kelas Dunia. Mal-mal tersebut selalu saja dipenuhi oleh pengunjung, hal ini oleh sebagian pengamat Ekonomi mengindikasikan potensi daya beli masyarakat yang besar (Julina dan Desrir, 2014). Melihat potensi ini banyak merk terkenal dan mewah kelas Dunia yang membuka tokonya di Indonesia dan semakin memanjakan sifat konsumerisme masyarakat Indonesia, sebut saja Lacoste, Versace, Giordano, Louis Vuitton, Jimmy Choo, Prada, Bally, Christian Loubuttin, dll. Kebutuhan akan barang mewah dan cara gaya hidup sebagian besar penduduk di Kota Denpasar merupakan sudah suatu keharusan yang dialami oleh setiap konsumen, Fenomena 
yang luar biasa ini, sudah terjadi dari dahulu hingga sampai saat ini. Keadaan ini yang membuat setiap produsen produk mewah dan berkelas ikut meramaikan pasar di Bali khususnya Kota Denpasar dengan tujuan mampu meningkatkan pendapatan melalui penjualan produk-produk yang ditawarkan.

Kemajuan teknologi dan meluasnya jaringan perusahaan membuat konsumen saat ini memiliki alternatif pilihan yang lebih banyak, tidak hanya yang dihasilkan produsen dalam negeri tetapi juga dari luar negeri (Parisa, 2014). Tren yang berkembang di suatu negara dengan mudah diakses oleh konsumen dari belahan dunia lain sehingga berpotensi memunculkan permintaan akan suatu produk yang lebih banyak dari masa sebelumnya. Hal ini dipermudah lagi dengan adanya perjanjian perdagangan antar negara yang membuat konsumen semakin mudah memperoleh produk asing karena dipasarkan juga di negaranya sendiri (Rahmawati et al., 2007). Tren membanjirnya produk-produk asing di pasar negara lain juga terjadi di Indonesia. Bahkan, sebagian konsumen Indonesia mempersepsikan bahwa produk-produk asing sering memiliki berbagai kelebihan dibanding produk dalam negeri. Walaupun secara kualitas kadangkala produk dalam negeri mampu bersaing dengan produk impor, namun kesenangan mengikuti tren terbaru membuat konsumen tetap memburu produk impor (Sreejesh, 2015). Penggunaan produk-produk impor ini juga dianggap dapat meningkatkan gengsi sehingga merasa lebih diakui oleh lingkungannya (Sudomo, 2014)

Bagi konsumen yang orientasi dirinya bertumpu pada prinsip, dalam mengambil keputusan membeli berdasarkan keyakinannya (Ayu dan Kerti, 2014). 
Ida Bagus Bayu DP, Pengaruh Brand Equity...

Sehingga keputusannya untuk membeli bukan hanya karena ikut-ikutan membeli dikarenakan produk-produk branded (bermerek) cenderung menjadi pilihannya dan tidak berpikir lebih lanjut akan manfaatnnya (Kambiz and Mohammad, 2012).

Kevin (2014) menyebutkan bahwa kekuatan merek terletak pada kemampuannya memikat konsumen untuk membeli produk yang diinginkannya. Merek penting bagi perusahaan untuk menunjukkan nilai produk yang ditawarkan ke pasar, namun merek tidak berarti jika tidak memiliki ekuitas yang kuat bagi pasar (Johan, 2010). Menurut Kotler dan Keller (2009:263), ekuitas merek adalah nilai tambah yang diberikan pada produk dan jasa. Ekuitas merek dapat tercermin dalam cara konsumen berpikir, merasa, dan bertindak dalam hubungannya dengan merek, dan juga harga, pangsa pasar, dan profitabilitas yang diberikan merek bagi perusahaan. Bagi perusahaan yang sadar akan makna penting dan strategisnya merek, ekuitas merek menjadi hal yang selalu diperhatikan dan pengukurannya dilakukan secara teratur, karena ekuitas merek dapat dianggap sebagai tambahan arus kas yang diperoleh melalui pengaitan nama merek dengan produk/jasa yang mendasarinnya (Eko dan Budi, 2013). Ekuitas merek yang kuat dapat menyebabkan minat beli konsumen/calon konsumen yang tinggi (Andrie dan Harold, 2013).

Konsumen akan memilih suatu merk tertentu yang mencerminkan atau memperkuat identitas diri mereka agar diterima di komunitas tertentu atau untuk meningkatkan gengsi orang tersebut secara individu. Kuenzel dan Halliday (2008:293) menyatakan bahwa orang biasanya melampui identitas diri mereka untuk mengembangkan identitas sosial. Dalam konteks pemasaran, pelanggan 
melakukannya dengan mengidentifikasi dan mengasosiasikan diri dengan merek yang mencerminkan dan memperkuat identitas diri mereka. Merk produk Lacoste misalnya, orang memilih merk Lacoste karena memberikan prestise dan kualitas yang baik dari segi bahan dan keawetan warna sehingga orang merasakan suatu peningkatan harga diri, atau tingkat gensi jika menggunakan produk Lacoste.

Brand preference seringkali ditemukan sebagai variabel yang langsung mempengaruhi keinginan konsumen untuk membeli brand. Preferensi merupakan kecenderungan akan sesuatu yang biasanya diperoleh setelah konsumen membandingkan sesuatu tersebut dengan sesuatu yang lainnya. Dengan demikian, brand preference merupakan kecenderungan seorang konsumen untuk menyukai sebuah merek dibandingkan yang lainnya sehingga akan membentuk keinginannya untuk membeli merek tersebut (Beatrice et al.,2014). Bensley dan Fisher (2003: 106) menyatakan bahwa brand preference timbul ketika seorang pelanggan memilih satu merek berdasarkan kebiasaan dan pengalaman yang dimiliki, tetapi dapat menerima pengganti merek produk tersebut jika merek yang dipilih telah sulit untuk diperoleh. Konsumen yang memiliki brand preference terlihat dari sikap mereka yang memilih produk berdasarkan ketertarikan dengan nama merek produk yang dianggap menarik, lebih menyukai satu merek produk yang dipilihnya daripada merek produk yang lain dan konsumen yang tetap lebih memilih merek produk tersebut dibandingkan dengan produk lainnya (Edwin, 2014). Brand Preference merupakan keyakinan-keyakinan atau informasi yang diterima oleh konsumen yang akan mempengaruhi perilakunya untuk memilih suatu merek tertentu untuk dibeli (Felly, 2015). 
Ida Bagus Bayu DP, Pengaruh Brand Equity...

Fenomena ini mengambarkan bahwa kencenderungan konsumen untuk membeli produk fashion karena pemakai berdasarkan simbol merk yang dikenakan. Konsumen menggunakan status produk sebagai simbol untuk mengkomunikasikan kepada kelompok referensi yang responnya sangat penting bagi pemakai produk (Yungki, 2010). Orang di Indonesia khususnya Bali baik diperkotaan maupun pedesaan termasuk orang yang sangat konsumtif dan gengsi memberikan peranan sangat besar dalam hal niat beli mereka, apalagi masyarakat di perkotaan yang juga gengsinya lebih tinggi, sehingga semakin mahal produk yang dijual semakin banyak yang membeli. Tidak heran Indonesia khususnya Bali menjadi salah satu tujuan utama ekspor produk dari luar Negeri, dikarenakan orang Indonesia termasuk gila produk luar Negeri berdasarkan gengsi di masyarakat.

Melalui pemaparan masalah yang telah dijabarkan, didukung dengan karya ilmiah dan teori tujuan dari karya ilmiah ini yang hendak dicapai 1) Bagaimana pengaruh brand equity terhadap brand preference pada produk pakaian Lacoste di Kota Denpasar, 2) Bagaimana pengaruh brand equity terhadap niat beli konsumen pada produk pakaian Lacoste di Kota Denpasar, 3) Bagaimana pengaruh brand preference terhadap niat beli konsumen pada produk pakaian Lacoste di Kota Denpasar, dan 4) Apakah brand preference memediasi pengaruh brand equity terhadap niat beli konsumen pada produk pakaian Lacoste di Kota Denpasar.

Suprapti (2010:68) persepsi merupakan sebuah proses yang harus dilalui oleh konsumen untuk memilih, mengorganisasi, menginterpretasi stimuli ke dalam sebuah gambaran yang bersifat koheren. Menurut Mangkunegara (2011:21) 
"Perilaku konsumen didefinisikan sebagai tindakan individu yang secara langsung terlibat dalam usaha memperoleh dan menggunakan barang-barang serta jasa ekonomis termasuk proses pengambilan keputusan yang mendahului dan menentukan tindakan-tindakan tersebut".

Menurut Assael (Kotler, 2012:221), terdapat empat jenis perilaku pembelian konsumen berdasarkan tingkat keterlibatan pembeli dan tingkat diferensiasi mereka, yaitu: Perilaku pembelian yang rumit : konsumen terlibat dalam perilaku pembelian yang rumit bila mereka sangat terlibat dalam pembelian dan sadar akan adanya perbedaan yang signifikan diantara berbagai merek. Perilaku pembelian pengurang ketidaknyamanan/ Disonasi : pada perilaku pembelian ini konsumen menjadi sangat terlibat dalam sebuah pembelian, namun melihat sedikit perbedaan diantara berbagai merek. Perilaku pembelian karena kebiasaan : perilaku pembelian ini terjadi bila terdapat pembelian produk dengan tingkat keterlibatan konsumen yang rendah, serta adanya perbedaan merek yang signifikan. Perilaku pembelian yang mencari variasi : pada perilakun ini situasi pembelian ditandai oleh adanya keterlibatan yang rendah oleh konsumen, namun terdapat perbedaan merek yang signifikan.

Asosiasi Pemasar Amerika (Kotler dan Amstrong, 2012) mendefinisikan merek sebagai nama, istilah, tanda, simbol, atau rancangan, atau kombinasi dari semuanya, yang dimaksudkan untuk mengidentifikasikan barang atau jasa atau kelompok penjualan dan untuk mendiferensiasikannya dari barang dan jasa pesaing. 
Memiliki merek yang kuat merupakan aspek vital bagi perusahaan. Sejumlah studi menemukan dampak positif dari memiliki merek kuat (Tjiptono, 2014): Efek berkaitan dengan produk, merek berhubungan positif dengan evaluasi produk, persepsi kualitas dan tingkat pembelian. Selain itu familiaritas dengan sebuah merek berpotensi meningkatkan costumer confidence, sikap terhadap merek, dan minat beli. Efek berkaitan dengan harga, brand leader mampu menetapkan harga lebih mahal, lebih kuat menghadapi situasi kenaikan harga dan lebih tahan terhadap perang harga dari para pesaing. Brand leader juga mampu meraih pangsa pasar pada tingkat yang lebih besar dibandingkan para pesaing (Tae and Jooyoung, 2010).

Efek berkaitan dengan pemasaran, konsumen cenderung bereaksi positif terhadap pengulangan iklan merek yang terkenal. Konsumen yang berkomitmen tinggi pada sebuah merek cenderung lebih mungkin bersikap divensif dan mengoreksi informasi negatif yang diterimanya. Hal ini menyebabkan merek kuat cenderung lebih mampu menghadapi situasi krisis.

Efek berkaitan dengan distribusi, produk yang memiliki merek kuat lebih mudah diterima para distributor dan mendapatkan tempat tersendiri dipasar. Gerai ritel juga lebih mungkin menonjolkan merek yang terkemuka guna menciptakan citra berkualitas.

Menurut Aaker (1997) dalam penelitian (Ria dan Gatot, 2014) ekuitas merek adalah serangkaian aset dan kewajiban yang terkait dengan sebuah merek, nama, simbolnya, yang menambah dan mengurangi nilai yang diberikan sebuah produk dan jasa kepada perusahaan atau pelanggan perusahaan tersebut. Menurut 
Kotler (2007) ekuitas merek adalah nilai tambah yang diberikan pada produk dan jasa. Nilai ini bisa dicerminkan dalam cara konsumen berfikir, merasa, dan bertindak terhadap merek, harga, pangsa pasar, dan profitabilitas yang dimiliki perusahaan. Aaker menjabarkan aset merek yang berkontribusi pada penciptaan Brand Equity dalam empat dimensi yaitu:

Brand awareness adalah kesanggupan seorang calon pembeli untuk mengenali, mengingat kembali suatu merek sebagai bagian dari suatu kategori merek tertentu. Bagian dari suatu kategori produk perlu ditekankan karena terdapat suatu hubungan yang kuat antara kategori produk dengan merek yang dilibatkan.

Brand Associations menurut (Aaker, 1997:160) dalam Edwin (2014) menulis bahwa asosiasi merek adalah segala hal yang berkaitan dengan ingatan mengenai sebuah merek. Sekumpulan asosiasi terhadap suatu merek akan membentuk citra merek (brand image) dan citra tersebut merupakan himpunan dan keyakinan yang timbul dari seseorang terhadap merek tertentu.

Brand Perceived quality dapat didefinisikan sebagai persepsi pelanggan terhadap keseluruhan kualitas atau keunggulan suatu produk atau jasa layanan berkaitan dengan apa yang diharapkan pelanggan dan perceived quality bersifat obyektif karena ditentukan oleh pelanggan.

Brand Loyalty merupakan suatu ukuran keterkaitan pelanggan kepada sebuah merek. Ukuran ini mampu memberi gambaran tentang mungkin tidaknya seorang pelanggan beralih ke merek lain, terutama jika pada merek tersebut 
didapati adanya perubahan, baik menyangkut harga ataupun atribut lain (Thiripurasundari and Natarajan, 2011).

Menurut American Marketing Association (AMA) merek (brand) yaitu nama, istilah, tanda, simbol, atau desain atau panduan dari hal-hal tersebut yang dimaksudkan untuk memberikan identitas bagi barang atau jasa yang dibuat atau disediakan suatu penjual atau kelompok penjual serta membedakannya dari barang atau jasa yang disediakan pesaing (Kotler and Armstrong, 2012:112). Brand preference merupakan tingkatan dimana konsumen menghendaki jasa yang disediakan oleh paritel lain dengan rangkaian pertimbangannya (Kotler and Keller, 2012:81). Merek merupakan suatu simbol yang kompleks yang dapat menyampaikan enam tingkat pengertian, antara lain: atribut (Attributes), suatu merek mendatangkan atribut tertentu ke dalam pikiran konsumen. Manfaat (Benefits), atribut yang ada harus diterjemahkan menjadi manfaat fungsional dan emosional. Nilai (values), merek juga menyatakan suatu tentang nilai pembuat atau Produsen. Budaya (Culture), merek dapat mempresentasikan budaya. Kepribadian (Personality), merek dapat menjadi proyeksi dan pribadi tertentu Pengguna (User) merek dapat mengesankan tipe konsumen tertentu.

Suprapti (2010:68) persepsi merupakan sebuah proses yang harus dilalui oleh konsumen untuk memilih, mengorganisasi, menginterpretasi stimuli ke dalam sebuah gambaran yang bersifat koheren. Menurut Mangkunegara (2011:21) "Perilaku konsumen didefinisikan sebagai tindakan individu yang secara langsung terlibat dalam usaha memperoleh dan menggunakan barang-barang serta jasa ekonomis termasuk proses pengambilan keputusan yang mendahului dan 
menentukan tindakan-tindakan tersebut". Perilaku konsumen (consumer behavior) adalah proses yang terjadi pada konsumen ketika memutuskan untuk membeli, apa yang dibeli, dimana, kapan, dan bagaimana membelinya. Sehingga, dapat disimpulkan bahwasanya perilaku konsumen merupakan suatu proses yang terusmenerus (berkesinambungan).

Berdasarkan beberapa pendapat tersebut dapat disimpulkan bahwa perilaku konsumen adalah semua kegiatan, tindakan serta proses psikologis yang mendorong tindakan tersebut pada saat sebelum membeli, ketika membeli, menggunakan produk dan jasa setelah melakukan hal-hal tersebut diatas atau kegiatan mengevaluasi.

Pengambilan keputusan konsumen akan berbeda-beda, tergantung pada jenis keputusan pembelian. Pembelian yang rumit dan mahal akan melibatkan lebih banyak pertimbangan yang diperlukan oleh pembelian. Menurut Philip Kotler (2012:221) terdapat empat jenis perilaku pembelian konsumen berdasarkan tingkat keterlibatan pembeli dan tingkat diferensiasi mereka, yaitu: perilaku pembelian yang rumit : konsumen terlibat dalam perilaku pembelian yang rumit bila mereka sangat terlibat dalam pembelian dan sadar akan adanya perbedaan yang signifikan diantara berbagai merek, dimana ini terjadi bila produknya mahal, jarang dibeli, berisiko dan sangat mengekspresikan kepribadian.

Perilaku pembelian pengurang ketidaknyamanan/ Disonasi : pada perilaku pembelian ini konsumen menjadi sangat terlibat dalam sebuah pembelian, namun melihat sedikit perbedaan diantara berbagai merek. Keterlibatan yang tinggi disadari adanya kenyataan bahwa pembelian tersebut mahal, jarang dilakukan dan 
berisiko. Setelah pembelian biasanya akan muncul ketidaksesuaian atau disonasi dari pengamatan terhadap hal-hal yang mengganggu mengenai produk yang dibeli atau kabar tentang hal-hal yang menyenangkan mengenai produk-produk sejenis lainnya.

Perilaku pembelian karena kebiasaan : perilaku pembelian ini terjadi bila terdapat pembelian produk dengan tingkat keterlibatan konsumen yang rendah, serta adanya perbedaan merek yang signifikan. Konsumen akan melakukan pembelian dengan mengambil merek tertentu secara berulang-ulang dimana hal tersebut dilakukan lebih karena kebiasaan daripada adanya kesetiaan terhadap suatu merek tertentu.

Perilaku pembelian yang mencari variasi : pada perilakun ini situasi pembelian ditandai oleh adanya keterlibatan yang rendah oleh konsumen, namun terdapat perbedaan merek yang signifikan. Situasi ini akan menyebabkan konsumen sering melakukan peralihan ke merek lain dan perpindahan merek ini biasanya karena mencari variasi dan bukan karena ketidakpuasan.

Pavlou (2011:78) menyatakan niat beli konsumen pada dasarnya merupakan faktor pendorong dalam pengambilaan keputusan pembelian terhadap suatu produk. Niat beli merupakan pernyataan mental konsumen yang merefleksikan rencana pembelian suatu produk dengan merek terntentu pengetahuan tentang niat beli konsumen terhadap produk perlu diketahui oleh para pemasar untuk mendeskripsikan perilaku konsumen pada masa yang akan datang. Minat beli terbentuk dari sikap konsumen terhadap suatu produk hal tersebut berasal dari keyakinan konsumen terhadap kualitas produk. Semakin rendah keyakinan 
konsumen terhadap suatu produk akan menyebabkan menurunkan minat beli konsumen. Menurut Kotler (2012:77) niat beli konsumen merupakan evaluasi purna beli atau hasil evaluasi setelah membandingkan apa yang dirasakan dengan harapannya. Niat beli merupakan sesuatu yang berhubungan dengan rencana konsumen untuk membeli produk tertentu, serta berapa banyak unit produk yang dibutuhkan pada periode tertentu.

Felly (2015) menemukan brand equity yang diterapkan mampu memberikan dampak positif dan signifikan dalam menciptakan brand preference bagi pelanggan. Ini pun diungkapkan oleh Kevin (2014) penerapan brand equity memberikan dampak positif dalam menciptakan brand preference konsumen. Ayu dan Kerti (2014) menyatakan hal yang sama dimana brand equity memiliki pengaruh yang positif terhadap brand preference. Edwin (2014) menyatakana hal bahwa brand equity secara positif berpengaruh terhadap brand preference. Berdasarkan pemahaman tersebut dapat dirumuskan hipotesis pertama sebagai berikut.

$\mathrm{H}_{1}$ : brand equity berpengaruh positif terhadap brand preference

Sudomo (2014) menemukan ekuitas merk yang diterapkan mampu memberikan dampak positif dan signifikan dalam menciptakan niat beli pelanggan. Ini pun diungkapkan oleh Yungki (2010) penerapan ekuitas merk mampu menciptakan dampak positif signifikan terhadap niat beli konsumen. Ini pun diungkapkan oleh Kevin (2014) penerapan brand equity memberikan dampak positif dalam meningkatkan niat beli konsumen. Ayu dan Kerti (2014) menyatakan hal yang sama dimana brand equity memiliki pengaruh yang positif 
Ida Bagus Bayu DP, Pengaruh Brand Equity...

terhadap niat beli konsumen. Berdasarkan pemahaman tersebut dapat dirumuskan hipotesis pertama sebagai berikut.

$\mathrm{H}_{2}$ : brand equity berpengaruh positif terhadap niat beli konsumen.

Edwin (2014) menyatakana hal bahwa brand preference secara positif berpengaruh terhadap niat beli konsumen. Brand preference sebagai ruang lingkup konsumen memberikan dampak positif signifikan terhadap niat beli konsumen pada produk (Felly, 2015). Yungki (2010) menyatakan bahwa brand preference konsumen berdampak positif signifikan terhadap niat beli pada produk. Sudomo (2014) menemukan brand preference yang diterapkan mampu memberikan dampak positif dan signifikan dalam meningkatkan niat beli pelanggan. Berdasarkan hasil penelitian tersebut, diajukan hipotesis ke tiga sebagai berikut.

$\mathrm{H}_{3}$ : brand preference berpengaruh positif terhadap niat beli konsumen.

Brand Preference konsumen sebagai variabel intervening memberikan pengaruh positif dan signifikan terhadap brand equity dan niat beli (Yungki, 2010). Felly (2015) membuktikan hal yang diantara hubungan positif brand preference dan brand equity niat beli memiliki pengaruh positif sebagai variabel mediasi. Ini pun diungkapkan oleh Kevin (2014) penerapan brand equity memberikan dampak positif terhadap niat beli konsumen melalui brand preference. Ayu dan Kerti (2014) menyatakan hal yang sama dimana brand equity memiliki pengaruh yang positif terhadap niat beli konsumen melalui brand preference. Edwin (2014) menyatakana hal bahwa brand equity secara positif 
berpengaruh terhadap niat beli konsumen yang dimediasi oleh brand preference. Berdasarkan hasil penelitian tersebut, diajukan hipotesis ke empat sebagai berikut. $\mathrm{H}_{4}$ : brand preference memediasi pengaruh brand equity terhadap niat beli konsumen secara positif.

\section{METODE PENELITIAN}

Karya ilmiah ini menggunakan metode mendeskripsikan atau memberi gambaran terhadap obyek yang diteliti melalui data sampel atau populasi sebagaimana adanya (Sugiyono, 2013:29). Penelitian dilakukan di Kota Denpasar. Lokasi ini dipilih karena Kota Denpasar merupakan pusat kota dengan pertumbuhan sektor ekonomi masyarakat sangat cepat, jumlah penduduk yang padat dan populasi yang cukup tinggi. Selain itu secara teknis, Kota Denpasar memenuhi kategori yang dinilai efektif dan efisien dalam menyelenggarakan penelitian yang relevan, mengingat dari segi pendapatan penduduk yang berdomisili dan bekerja di Denpasar memiliki rata-rata pendapatan UMR tertinggi dibandingkan dengan di wilayah lainnya (BPS, Kota Denpasar, 2014).

Obyek dalam penelitian adalah konsumen yang memiliki niat beli pada produk Lacoste di Kota Denpasar, yang tidak diketahui jumlahnya. Variabel brand equity terhadap niat beli konsumen yang dimediasi oleh brand preference secara signifikan.

Jenis data kuantitatif dan kualitatif yang dipergunakan seperti data jumlah konsumen, jawaban responden terhadap kuesioner dan seperti sejarah perusahaan, struktur organisasi dan aktivitas perusahaan.Sumber data primer dan sekunder yang dipergunakan seperti observasi dan pemberian kuesioner kepada responden 
dan sejarah berdirinya perusahaan, struktur organisasi perusahaan, dan jumlah karyawan.

Populasi dalam penelitian ini digunakan 11 indikator yang terdiri dari tiga pertanyaan dari variabel niat beli konsumen, empat pertanyaan dari brand equity dan empat pertanyaan dari brand preference sehingga jumlah responden yang digunakan pada konsumen yang akan melakukan pembelian terhadap produk Lacoste (Sugiyono, 2013:68).

Pengaruh langsung brand equity (X) terhadap brand preference (M) ditunjukkan oleh koefisien jalur a, pengaruh langsung brand equity (X) terhadap niat beli konsumen $(\mathrm{Y})$ ditunjukkan oleh koefisien jalur $\mathrm{c}$, dan pengaruh brand preference $(\mathrm{M})$ terhadap niat beli konsumen $(\mathrm{Y})$ ditunjukkan oleh koefisien jalur b.

Pengujian hipotesis mediasi digunakan uji Sobel dengan menguji kekuatan pengaruh tidak langsung variabel pengetahuan inovasi produk (X) terhadap variabel niat pembelian ulang (Y) melalui variabel kepuasan konsumen (M) dihitung dengan cara mengalikan koefisien jalur $\mathrm{X}$ terhadap $\mathrm{M}$ (a) dengan koefisien jalur M terhadap Y (b) atau ab. Standar error koefisien a dan b ditulis dengan $\mathrm{S}_{\mathrm{a}}$ dan $\mathrm{S}_{\mathrm{b}}$, besarnya standar error tidak langsung (indirect effect) $\mathrm{S}_{\mathrm{ab}}$.

\section{HASIL DAN PEMBAHASAN}

Uji validitas menyatakan sebuah instrumen dikatakan valid jika item yang mempunyai korelasi positif dengan kriterum (skor total) serta korelasi tinggi menunjukkan bahwa item tersebut mempunyai validitas yang tinggi pula. 
Tabel 1.

Rangkuman Hasil Uji Validitas

\begin{tabular}{clccc}
\hline No & Variabel & Indikator & Korelasi & Keterangan \\
\hline 1 & Brand Equity $(\mathrm{X})$ & $\mathrm{X} 1.1$ & 0,836 & Valid \\
& & $\mathrm{X} 1.2$ & 0,794 & Valid \\
& & $\mathrm{X} 1.3$ & 0,920 & Valid \\
& & $\mathrm{X} 1.4$ & 0,872 & Valid \\
2 & \multirow{2}{*}{ Brand Preference (M) } & M.1 & 0,867 & Valid \\
& & M.2 & 0,788 & Valid \\
& & M.3 & 0,726 & Valid \\
& \multirow{2}{*}{ Niat Beli (Y) } & M.4 & 0,818 & Valid \\
& & Y.1 & 0,794 & Valid \\
& & Y.2 & 0,857 & Valid \\
& & & 0,893 & Valid \\
\hline
\end{tabular}

Sumber: data diolah, 2018

Tabel 1 diketahui bahwa masih-masing indikator variabel memiliki nilai person correlation lebih besar dari 0,30, maka ini berarti indikator/pertanyaan yang digunakan layak digunakan untuk mengukur apa yang seharusnya diukur, dan dapat mengungkap data dari variabel yang diteliti secara tepat.

Tabel 2.

Hasil Uji Reliabilitas

\begin{tabular}{clccc}
\hline \multirow{2}{*}{ No } & & Variabel & $\begin{array}{c}\text { Cronbadh's } \\
\text { Alpha }\end{array}$ & Keterangan \\
\hline 1 & Brand Equity $(\mathrm{X})$ & 0,877 & Reliabel \\
2 & Brand Preference $(\mathrm{M})$ & 0,802 & Reliabel \\
3 & Niat Beli (Y) & 0,796 & Reliabel \\
\hline
\end{tabular}

Sumber: data diolah, 2018

Tabel 2 diketahui bahwa nilai Cronbach's Alpha untuk masing-masing variabel $>0,6$, ini berarti alat ukur tersebut akan memberikan hasil yang konsisten apabila alat ukur tesebut digunakan kembali untuk meneliti obyek yang sama.

Output hasil SPSS pengujian pengaruh variabel brand equity (X) terhadap niat beli konsumen (Y) dengan mediasi brand preference (M) digambarkan dengan model diagram jalur seperti pada Gambar 2 berikut. 


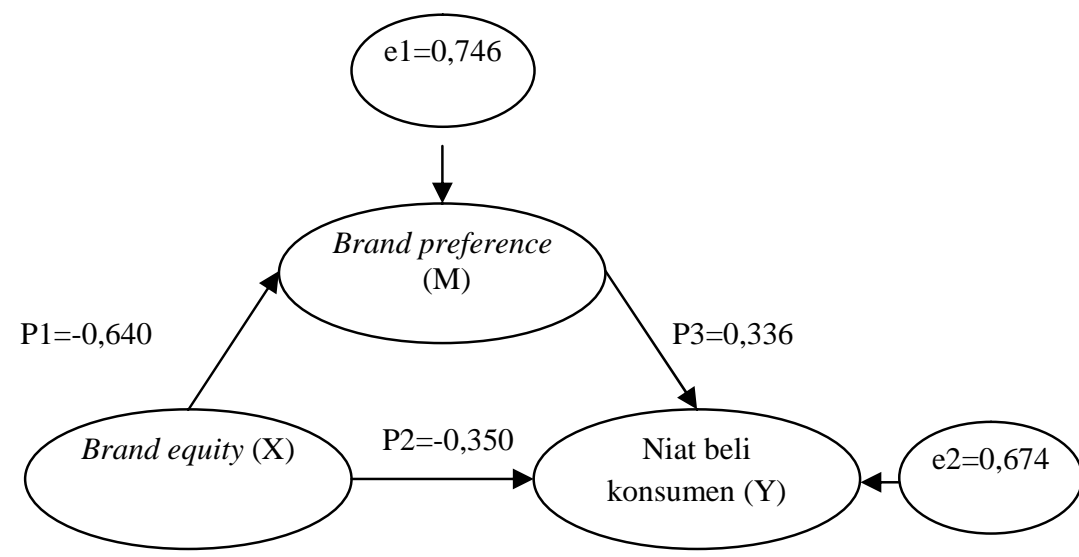

\section{Gambar 1.Model Jalur Brand Preference Memediasi Brand Equity Pada Niat Beli Konsumen}

Gambar 1 menunjukkan nilai koefisien jalur pada model pengaruh brand equity terhadap variabel niat beli konsumen melalui brand preference. Berdasarkan informasi pada Gambar 1 diketahui bahwa koefisien jalur pengaruh brand equity terhadap variabel niat beli konsumen setelah variabel brand preference dimasukan ke dalam model bernilai 0,336 tidak bernilai 0 , yang berarti brand preference memediasi pengaruh positif brand equity terhadap niat beli konsumen pada produk Lacoste di Kota Denpasar.

Output hasil SPSS hasil pengujian pengaruh variabel brand equity (X) terhadap brand preference $(\mathrm{M})$ disajikan berdasarkan persamaan strukturalnya adalah sebagai berikut:

$$
\begin{array}{r}
\mathrm{M}=0,640 \mathrm{X}+\mathrm{e}_{1} \\
\mathrm{Pe}_{\mathrm{i}}=\sqrt{1-R_{1}^{2}} \ldots \ldots \ldots \ldots \ldots \ldots \ldots \ldots \ldots \ldots \ldots \ldots \ldots \ldots \\
\mathrm{Pe}_{1}=\sqrt{\left(1-R_{1}^{2}\right)}=\sqrt{1-0,443}=0,746
\end{array}
$$


Output hasil SPSS hasil pengujian pengaruh variabel brand equity (X) terhadap niat beli konsumen (Y) disajikan berdasarkan persamaan strukturalnya adalah sebagai berikut:

$$
\mathrm{Y}=0,350 \mathrm{X}+\mathrm{e}_{1}
$$

Output hasil SPSS hasil pengujian pengaruh variabel brand preference (X) terhadap niat beli konsumen (Y) disajikan berdasarkan persamaan strukturalnya adalah sebagai berikut:

$$
\mathrm{Y}=0,336 \mathrm{M}+\mathrm{e}_{1}
$$

$$
\begin{aligned}
& \mathrm{Pe}_{\mathrm{i}}=\sqrt{1-R_{1}^{2}} \\
& \mathrm{Pe}_{2}=\sqrt{\left(1-R_{1}^{2}\right)}=\sqrt{1-0,545}=0,674
\end{aligned}
$$

Nilai determinasi total sebesar 0,748 mempunyai arti bahwa sebesar 74,8\% variasi niat beli konsumen dipengaruhi oleh variabel brand equity dan brand preference, sedangkan sisanya sebesar 25,2 persen dijelaskan oleh faktor lain yang tidak dimasukkan ke dalam model.

Brand equity berpengaruh positif signifikan terhadap niat beli konsumen dengan nilai standardized coefficients beta sebesar 0,350 dan nilai sig t sebesar $0,000<0,05$, oleh karena nilai standardized coefficients beta sebesar 0,350 dengan nilai sig $\mathrm{t}=0,000$ maka $\mathrm{H}_{0}$ diterima. Hal ini berarti variabel brand equity berpengaruh positif dan signifikan secara parsial terhadap niat beli konsumen pada produk Pakaian Lacoste di Kota Denpasar.

Brand preference berpengaruh positif signifikan terhadap niat beli konsumen dengan nilai standardized coefficients beta sebesar 0,356 dan nilai sig t sebesar $0,000<0,05$, oleh karena nilai standardized coefficients beta sebesar 0,356 
dengan nilai sig $\mathrm{t}=0,000$ maka $\mathrm{H}_{0}$ diterima. Hal ini berarti variabel brand preference berpengaruh positif dan signifikan secara parsial terhadap niat beli konsumen pada produk Pakaian Lacoste di Kota Denpasar.

Berdasarkan hasil dari koefisien jalur pada hipotesis penelitian, maka dapat digambarkan hubungan kausal antar variabel brand preference memediasi pengaruh brand equity terhadap niat beli konsumen. Perhitungan pengaruh antar variabel dirangkum dalam Tabel 3.

Tabel 3.

Pengaruh langsung dan pengaruh tidak langsung serta pengaruh total brand equity (X) terhadap niat beli konsumen (Y) dengan mediasi brand preference (M)

\begin{tabular}{llccc}
\hline Pengaruh Variabel & $\begin{array}{c}\text { Pengaruh } \\
\text { Langsung }\end{array}$ & $\begin{array}{c}\text { Pengaruh Tidak } \\
\text { Langsung M } \\
(\mathbf{p 1 ~ x ~ p 3 ) ~}\end{array}$ & Pengaruh Total \\
\hline P1 & $\mathrm{X} \rightarrow \mathrm{M}$ & 0,640 & - & 0,640 \\
P2 & $\mathrm{X} \rightarrow \mathrm{Y}$ & 0,350 & - & 0,350 \\
P3 & $\mathrm{M} \rightarrow \mathrm{Y}$ & 0,336 & - & 0,336 \\
$\mathrm{P} 4$ & $\mathrm{X} \rightarrow \mathrm{M} \rightarrow \mathrm{Y}$ & 0,640 & 0,215 & 0,885 \\
\hline Sumber & Data
\end{tabular}

Sumber: Data diolah, 2018

Berdasarkan diagram jalur hasil perhitungan didapatkan perbandingan nilai z hitung sebesar 2,699 > z tabel sebesar 1,96, maka Ho ditolak dan Hi diterima. Artinya brand preference memediasi pengaruh brand equity terhadap niat beli konsumen pada produk Lacoste di Kota Denpasar.

Hasil analisis data menunjukkan brand equity memberikan pengaruh positif terhadap brand preference, oleh karena itu brand equity yang dimiliki oleh produk Lacoste harus ditingkatkan sehingga mampu menambah nilai positif brand preference pada produk di mata konsumen sehingga lebih dipercaya dan dapat meningkatkan niat beli konsumen terhadap produk Lacoste. 
Hasil penelitian ini searah dengan penelitian Felly (2015) menemukan brand equity yang diterapkan mampu memberikan dampak positif dan signifikan dalam menciptakan brand preference bagi pelanggan. Ini pun diungkapkan oleh Kevin (2014) penerapan brand equity memberikan dampak positif dalam menciptakan brand preference konsumen. Ayu dan Kerti (2014) menyatakan hal yang sama dimana brand equity memiliki pengaruh yang positif terhadap brand preference. Edwin (2014) menyatakana hal bahwa brand equity secara positif berpengaruh terhadap brand preference.

Berdasarkan hasil analisis data diketahui bahwa brand equity berpengaruh signifikan positif terhadap niat beli konsumen. Produk Lacoste perlu meningkatkan brand equity yang ditawarkan kepada konsumen sehingga konsumen memahami apa yang menjadi keunggulan dan kualitas daripada produk lacoste, sehingga efektif bagi perusahaan untuk meningkatkan niat beli konsumen.

Hasil penelitian ini didukung oleh penelitian Sudomo (2014) menemukan ekuitas merk yang diterapkan mampu memberikan dampak positif dan signifikan dalam menciptakan niat beli pelanggan. Ini pun diungkapkan oleh Yungki (2010) penerapan ekuitas merk mampu menciptakan dampak positif signifikan terhadap niat beli konsumen. Ini pun diungkapkan oleh Kevin (2014) penerapan brand equity memberikan dampak positif dalam meningkatkan niat beli konsumen. Ayu dan Kerti (2014) menyatakan hal yang sama dimana brand equity memiliki pengaruh yang positif terhadap niat beli konsumen.

Berdasarkan hasil analisis data diketahui bahwa brand preference terhadap niat beli konsumen berpengaruh signifikan positif. Lacoste harus melihat brand 
Ida Bagus Bayu DP, Pengaruh Brand Equity...

preference sebagai persepsi dan kepercayaan konsumen terhadap merek barang atau jasa yang memperkuat loyalitas merek dan meningkatkan niat beli. produk Lacoste di Kota Denpasar harus berusaha untuk menciptakan suatu image yang baik, tepat dan sesuai dengan selera konsumen terhadap produk yang dihasilkan.

Hasil penelitian ini didukung oleh penelitian Edwin (2014) menyatakana hal bahwa brand preference secara positif berpengaruh terhadap niat beli konsumen. Brand preference sebagai ruang lingkup konsumen memberikan dampak positif signifikan terhadap niat beli konsumen pada produk (Felly, 2015). Yungki (2010) menyatakan bahwa brand preference konsumen berdampak positif signifikan terhadap niat beli pada produk. Sudomo (2014) menemukan brand preference yang diterapkan mampu memberikan dampak positif dan signifikan dalam meningkatkan niat beli pelanggan.

Berdasarkan hasil analisis data diketahui bahwa brand preference dapat memediasi pengaruh brand equity terhadap niat beli konsumen secara positif. Produk Lacoste di Kota Denpasar harus memperhatikan niat beli konsumen yang dapat dibantu dengan brand preference sebagai salah satu bentuk pengenalan produk terhadap konsumen yang efektif dengan meningkatkan brand equity sehingga mampu bersaing untuk merebut niat beli konsumen.

Hasil penelitian ini sesuai dengan penelitian Yungki (2010) yang membuktikan brand preference konsumen sebagai variabel intervening memberikan pengaruh positif dan signifikan terhadap brand equity dan niat beli. Felly (2015) membuktikan hal yang diantara hubungan positif brand preference dan brand equity niat beli memiliki pengaruh positif sebagai variabel mediasi. Ini 
pun diungkapkan oleh Kevin (2014) penerapan brand equity memberikan dampak positif terhadap niat beli konsumen melalui brand preference. Ayu dan Kerti (2014) menyatakan hal yang sama dimana brand equity memiliki pengaruh yang positif terhadap niat beli konsumen melalui brand preference. Edwin (2014) menyatakana hal bahwa brand equity secara positif berpengaruh terhadap niat beli konsumen yang dimediasi oleh brand preference.

\section{SIMPULAN DAN SARAN}

Berdasarkan pada pembahasan pada bab-bab sebelumnya, maka adapun halhal yang dapat disimpulkan yaitu brand equity berpengaruh positif dan signifikan terhadap brand preference pada produk Lacoste di Kota Denpasar. Brand equity berpengaruh positif dan signifikan terhadap niat beli konsumen pada produk Lacoste di Kota Denpasar. Brand preference berpengaruh positif dan signifikan terhadap niat beli konsumen pada produk Lacoste di Kota Denpasar. Brand preference memediasi pengaruh positif brand equity terhadap niat beli konsumen pada produk Lacoste di Kota Denpasar.

Berdasarkan simpulan, saran-saran yang dapat dilakukan Lacoste sebagai dalam menghadapi masalah brand equity, harus memperhatikan design, model dan kualitas produk dengan inovasi-inovasi yang lebih menarik berbeda dengan merek pesaing sehingga mudah di ingat oleh konsumen dan memiliki niat untuk membeli. Lacoste harus mampu menghadapi masalah brand preference, dengan selalu memperlihatkan merk lacoste dari segi tampilan model dan warna sehingga konsumen tahu bahwa yang akan dibelinya adalah benar-benar merk lacoste tidak merek lainnya ataupun barang tiruan. Lacoste di Kota Denpasar harus mampu 
menghadapi masalah niat beli konsumen, pihak manajemen harus lebih giat lagi untuk memasarkan produknya kepada konsumen baik secara langsung dari pelayan toko, melalui media cetak seperti brosur, spanduk, baliho ataupun elektronik sehingga konsumen yakin yang dibeli adalah produk merk lacoste yang sangat terkenal dan berkualitas.

\section{REFERENSI}

Andrie Ch. Salhuteru dan Harold Hursepuny, (2013). Analisa Ekuitas Merek terhadap Keputusan Pembelian Sepeda Motor Merek Yamaha di PT Hasjrat Abadi Cabang Ambon. Jurnal Manajemen Ekonomi dan Akuntansi. 2(1): h: 1-122

Beatrice Clementia Halim, Diah Dharmayanti, dan Ritzky Karina. (2014). Pengaruh Identitas merk Toyota terhadap Timbulnya Preferensi Merek dan Niat Pembelian Kembali Konsumen terhadap merek Toyota. Jurnal Manajemen Pemasaran Petra. 2(1): h: 1-11

Edwin Sanjaya. (2014). Pengaruh Brand Equity terhadap Purchase Intention melalui Brand Preference Pada Produk OT. Sunlife Financial di Surabaya. Jurnal Manajemen Ekonomi dan Bisnis. 2(1): h: 1-7

Eko Nurdin Kurnianto dan Budi Astuti, ((2013)). Analisis pengaruh komponen pembentuk ekuitas merek terhadap minat beli. Jurnal Manajemen Ekonomi Nasional. 4(1): h: 458-466

Felly Liliyana Soenyoto. (2015). The Impact of Brand Equity on Brand Preference and Purchase Intention in Indonesia's Bicycle Industry: A Case Study of Polygon. International Journal Ibuss Management. 3(2): h: 99-108

Johan wahyudi Amzah, (2013). Pengaruh gengsi, kepuasan dan komunikasi perusahaan terhadap woth of mouth dan niat beli kembali dengan variabel antara identifikasi merk (kasus pada produk Blacberry di Surabaya). Jurnal Ekonomi Erlangga. pp.1-128

Julina dan Desrir Miftah, (2014). Perbedaan perspektif konsumen berdasarkan gender terhadap niat beli produk asing. Jurnal Parallela. 1(1): h:1-88

Kambiz Heidarzadeh Hanzaee and Mohammad Javad Taghipourian, (2012). The Effects of Brand Credibility and Prestige on Consumers Purchase Intention in Low and High Product Involvement. Journal Basic. Appl. Sci. Res., 2(2): h: 1281-1291 
Kevin Goenawan, (2014). Pengaruh produk attributes, brand name, product price, dan social influence terhadap purchase intention Android Smartphone di Surabaya. Jurnal Ilmiah Ekonomi. 3(1): h: 1-17

Kuenzel, Sven \& Sue Vaux Halliday. (2008), "Investigating Antecedents and Consequences of Brand Identification". Journal of Product \& Brand Management. 293-304

Kotler, P. dan Keller, K.L.,(2007), "Manajemen Pemasaran", Cet 2, Edisi 12, Jilid 1, Alih bahasa: Benyamin Molan. Penerbit PT INDEKS.

Kotler, Philip and G. Armstrong. (2012). Principles of Marketing. 14th ed. New Jersey: Prentice Hall.

Parisa Valavi, (2014). Factors Influencing Mobile Services Adoption: A BranEquity Perspective. International Journal of Research Social Sciences. 4(3): h:1-18

Pavlou, P. A. (2011). Consumer Acceptance of Electronic Commerce: Integrating Trust and Risk with the Technology Acceptance Model. International Journal of Electronic Commerce, 7 (3): h: 69-103.

Rahmawati Setyaningsih, Suyudi Mangunwihardjo, Harry Soesanto, (2007). Analisis faktor-faktor yang mempengaruhi ekuitas merk untuk meningkatkan minat beli ulang (studi kasus pada kedai kopi Dome di Surabaya). Jurnal Studi Manajemen dan Organisasi. 4(2): h: 30-43

Saadia Shabnam. (2013). Proposed Model for Predicting Environmental Purchase Behavior of Consumers. Journal European Academic Research. 1(4) h: 444-466

Sreejesh, S., (2015). Consumers' Perceived Brand Aspiration and Its Impact on Intention to Pay Price Premium: Moderating Role of Brand Jealousy. Journal Theoretical Economics Letters. 5(1): h: 273-284

Sudomo, St. (2014). Pengaruh ekuitas merek terhadap keputusan pembelian pasta gigi Pepsodent di Kabupaten Bantul. Jurnal JBMA. 1(2): h: 33-48

Tjiptono Fandy. (2014). Strategi Pemasaran edisi ketiga, Andi Offset, Yogyakarta

Yungki Hary Wibisono, (2010). Faktor-faktor yang mempengaruhi perilaku pembelian dengan perilaku niat sebagai variabel intervening pada situs kaskus. Artikel ilmiah. 25(1), pp.1-8 